\title{
TÜKÖRBE NÉZVE
}

\section{Az EducATio ${ }^{\oplus}$ Folyóirat a HAZAi NEVELÉSTUDOMÁNYI LAPOK KÖZÖTT}

\author{
POLÓNYI ISTVÁN \\ Debreceni Egyetem Bölcsészettudományi Kar Nevelés- és Müvelődéstudományi Intézet
}

Beérkezett: 2021. április 20., elfogadva: 2021. október 14.

Ennek a tanulmánynak az a célja, hogy megvizsgálja fennállásának 30 éves évfordulóján az Educatio folyóirat néhány tudománymetriai jellemzőjét. Az írás elemzi a folyóirat egyes tartalmi, mennyiségi jellemzőjét és a neveléstudomány területén mérhető súlyát, jelentőségét és hatását összehasonlítva a másik három jelentős magyar pedagógiai folyóirattal: a Magyar Pedagógiával, az Iskolakultúrával és az Új Pedagógiai Szemlével. Ezen túlmenően megvizsgálja, hogy a hazai neveléstudomány jelentősebb műhelyeinek tagjai mennyit publikálnak az Educatióban és mennyit hivatkoznak a folyóirat írásaira.

Kulcsszavakः az Educatio folyóirat idézettsége, a neveléstudományi műhelyek tagjainak publikációi

The purpose of this study is to examine some of the scientific metrics of the journal Educatio on the occasion of its 30 th anniversary. The article analyzes some of the content and quantitative features of the journal and its measurable weight, significance and impact in the field of educational research, comparing it with the other three major Hungarian pedagogical journals: Magyar Peadgógia (Hungarian Pedagogy), Iskolakultúra (School Culture) and Új Pedagógiai Szemle (the New Pedagogical Review). In addition, the study examines how much the teaching and research members of the most significant workshops in Hungarian education publish in Educatio and how much they refer to the journal's writings.

Keywords: citation characteristics of the journal Educatio, publications of members of educational workshops

Levelező szerző: Polónyi István, Debreceni Egyetem Bölcsészettudományi Kar, Nevelés- és Művelődéstudományi Intézet, 4032 Debrecen, Egyetem tér 1. E-mail: istvan.polonyi@arts.unideb.hu 


\section{Bevezetés}

$\mathrm{A}$ z Educatio 30 éves lett. Az évforduló alkalmat teremt a tükörbe nézésre, arra, hogy megvizsgáljuk a folyóirat néhány tudománymetriai jellemzőjét, összehasonlítva a magyar folyóiratpiac másik három neveléstudományi folyóiratával, az Iskolakultúrával, a Magyar Pedagógiával és az Új Pedagógiai Szemlével.

Soós és szerzőtársa felsorolja - jóllehet tévesnek tartja - a tudománymetria következő felfogásait:

- publikációs statisztikák elöállítása (adminisztratív felfogás),

- tudományos teljesítmény mérése (kutatói felfogás), valamint

- kutatásértékelés (döntéshozói felfogás) (Soós-Vida 2019).

Egy másik írásban Soós megadja az általa helyesnek vélt definíciót is, miszerint „Az »elméleti« tudománymetria mint kutatási terület [...] a tudomány szerveződésének, müködésének, dinamikájának (fóként a tudományos kommunikációra irányuló) empirikus kvantitatív vizsgálatát célozza. Ennek egy ága, az ún. értékelő tudománymetria foglalkozik a tudományos teljesítmény modellezésével és mérésével." (Soós-Kiss-Lackner 2020: 960.)

Soós és szerzőtársai azt is hangsúlyozzák, hogy a tudománymetria gyors fejlődése gyakran vezet ahhoz, hogy a kutatásértékelési indikátorokat - a számszerüsíthetőség „büvöletében” - nem kellő körültekintéssel használják, és az általuk kapott eredményeket abszolutizált módon értelmezik (Soós-Kiss-Lackner 2020: 958).

Mindezek előrebocsátásával és szem előtt tartásával igyekszünk a négy folyóiratot összehasonlítani. Az adatok és a számok közreadásával az olvasóra bízzuk az értékelés véleményezését.

A neveléstudományi folyóiratok tudománymetriai összehasonlítása nem előzmény nélküli. Valamennyire előzménynek tekinthető - bár ez nem tudománymetriai elemzés volt - a 2004. évi Országos Neveléstudományi Konferencia folyóirat-szekciója, valamint Csapó Benő számos, a Magyar Pedagógia folyóirattal foglalkozó írása (pl. Csapó 1991, 1992, 2005).

Az első szélesebb körben ismert tudománymetriai elemzés Tóth és szerzőtársai munkája volt, ami 1997 és 2007 között vizsgálta a magyar neveléstudományi folyóiratokat, nemzetközi kitekintéssel is. (Tóth-Toman-Cserpes 2008.) Ez az elemzés azonban az Iskolakultúra, a Magyar Pedagógia és az Új Pedagógiai Szemle mellett az Educatióra nem terjedt ki. Bíró ugyancsak nemzetközi térre is kiterjedő elemzései közel hasonló évfolyamokon (1996-2006) vizsgálták a négy magyar neveléstudományi folyóiratot, köztük az Educatiót (Biró 2009a, 2009b).

Az utóbbi időben Nagy Gyula munkái elemezték a Magyar Pedagógia folyóiratot, helyenként kitekintve a többi háromra is (Nagy 2016, 2019; Nagy-Molnár 2017).

A négy neveléstudományi folyóirat sajátos elemzését adják Molnár és munkatársai a társszerzői hálózatok vizsgálatával (Molnár-Pintér-Tóth 2018).

A neveléstudományi doktori iskolák hallgatóinak többek között az itt elemzett négy neveléstudományi folyóiratban történő publikációit vizsgálta Soós és szerzőtársa (SoósVida 2019). 
Meg kell még említeni Sasvári munkáit, aki az MTA IX. osztály folyóiratait elemezve kitér az Educatio és az Iskolakultúra néhány tudománymetriai jellemzőjére (SasváriUrbanovics 2020, 2021; Sasvári 2019).

\section{Az oktatáskutatási lapok profiljai}

A Magyar Pedagógia 1892-ben lett alapítva, s az 1947-től tartó szüneteltetés után 1961ben indult újra mint az MTA Pedagógiai Bizottságának folyóirata, amely 2020-ban a 120. évfolyamánál tart. Az Iskolakultúrát 1991-ben alapították, 2021-ben a 31. évfolyamát jegyzi. Az Új Pedagógiai Szemle elődje a Pedagógiai Szemle 1951-ben látott először napvilágot, amely 1991-től jelenik meg Uj Pedagógiai Szemle néven. Meghaladja jelen írás kereteit, hogy mélyebb történelmi áttekintést mutassunk be az egyes lapok alapításáról, alapítóiról és múltjáról - pedig ez nyilvánvalóan hozzájárulhatna az egyes lapok arculatának megismeréséhez.

A négy között a legfiatalabb az Educatio, melynek első száma 1992-ben jelent meg ${ }^{1}$, a jelenlegi a 30. évfolyam.

$\mathrm{A} z$ Educatio folyóiratnak 2020 végéig 114 kötete jelent meg, valamennyi tematikus szerkesztésü volt. A tematika alapján nagyobb témacsoportba sorolva a megjelent számokat, három nagy témacsoport teszi ki a megjelent számok felét: az iskola társadalmi, gazdasági környezetével foglalkozó témák, az oktatáspolitikai témák és az iskola belső világával szociológiai aspektusból foglalkozó témák. Hozzátéve, hogy részint egy ilyen besorolás mindig szubjektív, részint pedig, hogy a témák túlnyomó többsége valójában oktatáspolitikai és nevelésszociológiai.

A tematikák alapján az Educatio folyóiratot leginkább az oktatáskutatással, a nevelésszociológiával foglalkozó értelmiségiek lapjaként lehetne azonosítani. Önmeghatározása szerint - ami a korábbi számok belső oldalán olvasható volt - „interdiszciplináris szemle azok számára, akik az oktatás társadalmi összefüggéseit keresik”. Homloklapján pedig hat tudomány van felsorolva: pedagógia, szociológia, ökönómia, história, pszichológia, politológia.

A hazai folyóiratpiacon található hasonlóan neveléstudományi tematikájú jelentős periodikák közül az egyik az Iskolakultúra, amely önmeghatározása szerint az oktatássalneveléssel, az iskola belső világával, illetve az oktatási rendszer jellemzőivel kapcsolatos írásokat közöl ${ }^{2}$. A másik a Magyar Pedagógia, amely a „tágan értelmezett neveléstudomány minden területéről közöl tanulmányokat, empirikus vizsgálat eredményeit összegző írást éppúgy, mint elméleti elemzést vagy egy kutatási terület eredményeinek átfogó, szintetizáló jellegü bemutatását”. ${ }^{3} \mathrm{~A} z$ Uj Pedagógiai Szemle célja pedig: „kutatói és tanári beszámolókkal, határainkon túli neveléstudományi kitekintéssel [...] fórumot biztosítani pedagógusok és oktatáskutatók számára" ${ }^{4}$

$\mathrm{A} z$ ilyen önmeghatározások persze sohasem adnak pontos képet.

\footnotetext{
Az Educatio alapításáról lásd Géczi 2001.

http://www.iskolakultura.hu/index.php/iskolakultura/ [Letöltve: 2021. 03. 17.]

http://www.magyarpedagogia.hu/?pid=20 [Letöltve: 2021. 03. 17.]

https://folyoiratok.oh.gov.hu/uj-pedagogiai-szemle [Letöltve: 2021. 03. 17.]
} 
Ha megnézzük az MTA tudományos osztályai által elfogadott folyóiratlistákat, s azokban a vizsgált lapokat, akkor is kapunk valamilyen képet az egyes periodikák profiljáról (2020, év végi állapot szerint) (1. táblázat).

1. táblázat: A vizsgált periodikák az MTA tudományos bizottságok folyóiratlistáin

\begin{tabular}{|c|c|c|c|c|c|c|c|}
\hline & \multicolumn{2}{|c|}{$\begin{array}{l}\text { MTA I. Nyelv- és } \\
\text { Irodalomtudo- } \\
\text { mányok Osztálya }\end{array}$} & \multicolumn{2}{|c|}{$\begin{array}{l}\text { MTA II. Filozófiai } \\
\text { és Történettudo- } \\
\text { mányok Osztálya }\end{array}$} & \multicolumn{3}{|c|}{$\begin{array}{c}\text { MTA IX. Gazdaság-és } \\
\text { Jogtudományok } \\
\text { Osztálya }\end{array}$} \\
\hline & 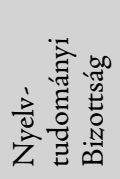 & 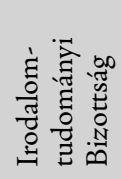 & 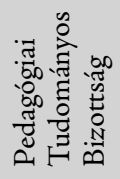 & 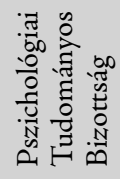 & 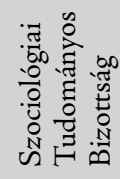 & 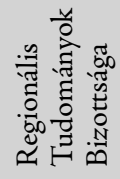 & 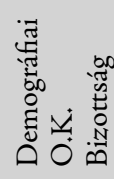 \\
\hline Educatio & & $\mathrm{x}$ & $\mathrm{x}$ & $\mathrm{x}$ & $\mathrm{x}$ & $\mathrm{x}$ & $\mathrm{x}$ \\
\hline Iskolakultúra & & $\mathrm{x}$ & $\mathrm{x}$ & $\mathrm{x}$ & $\mathrm{x}$ & $\mathrm{x}$ & \\
\hline Magyar Pedagógia & $\mathrm{x}$ & & $\mathrm{x}$ & $\mathrm{x}$ & & & \\
\hline Uj Pedagógiai Szeme & $\mathrm{x}$ & & $\mathrm{x}$ & & & & \\
\hline
\end{tabular}

Forrás: MTA honlapja alapján

A táblázat tanúsága szerint az Educatio és az Iskolakultúra látszik a legszélesebb és a Magyar Pedagógia, valamint az Új Pedagógiai Szemle a legszűkebb profilúnak az MTA makro szinten képviselte tudományos mezőben. Ez azonban inkább csak a befogadás általános jellege, ami szükségszerűen nem esik egybe a publikált írások mondandójával. Ugyanakkor a táblázat az egyes folyóiratok nyitottságát is jellemzi a különböző tudományterületekre.

Egy másik lehetőség, ha megvizsgáljuk a négy folyóirat elmúlt időszakában (itt mi három évfolyamot ${ }^{5}$ néztünk meg) megjelent írások szerzőinek tudományos profilját, akkor a lapok arculatáról talán valamivel pontosabb képet alkothatunk. A 2. táblázat az egyes folyóiratok ismétlődő szerzőinek ${ }^{6}$ „tudományos profilját” mutatja. Az adatok tanúsága szerint az Educatio fó profilja a neveléstudomány és a nevelésszociológia, az Iskolakultúráé és a Magyar Pedagógiáé a neveléstudomány és a pszichológia, az Üj Pedagógiai Szemléé pedig a neveléstudomány, a szociológia és a pedagógia.

Megvizsgáltuk, hogy ezek a folyóiratok mennyire széles profilúak, mennyire csak a neveléstudomány lapjai, mivel az Educatio folyóirat esetében gyakran hangsúlyozzák a szélesebb profilt. Elemeztük három tudományterület - a neveléstudomány, a szociológia és a pszichológia - vezető oktatóinak a négy vizsgált folyóiratban közreadott publikációit. A vizsgálatba négy tudományegyetem (DE, ELTE, PTE, SZTE) neveléstudományi, szociológiai és pszichológiai intézetei egyetemi tanárainak és docenseinek publikációit vettük górcső alá az MTMT alapján. (Lásd melléklet 1., 2. és 3. táblázat.)

A megjelent elmúlt három évfolyam az Educatio, az Iskolakultúra és az Új Pedagógiai Szemle esetében a 2018-2019-2020, a Magyar Pedagógia esetében a 2017-2018-2019 évjárat volt - adatbázis OPKM WebOPAC https://opac.opkm.hu/pages/modules/opac/opac.php?fn=as

6 Mindegyik folyóiratnál sorrendben az első 10 leggyakrabban publikáló szerzőt vizsgáltuk. 


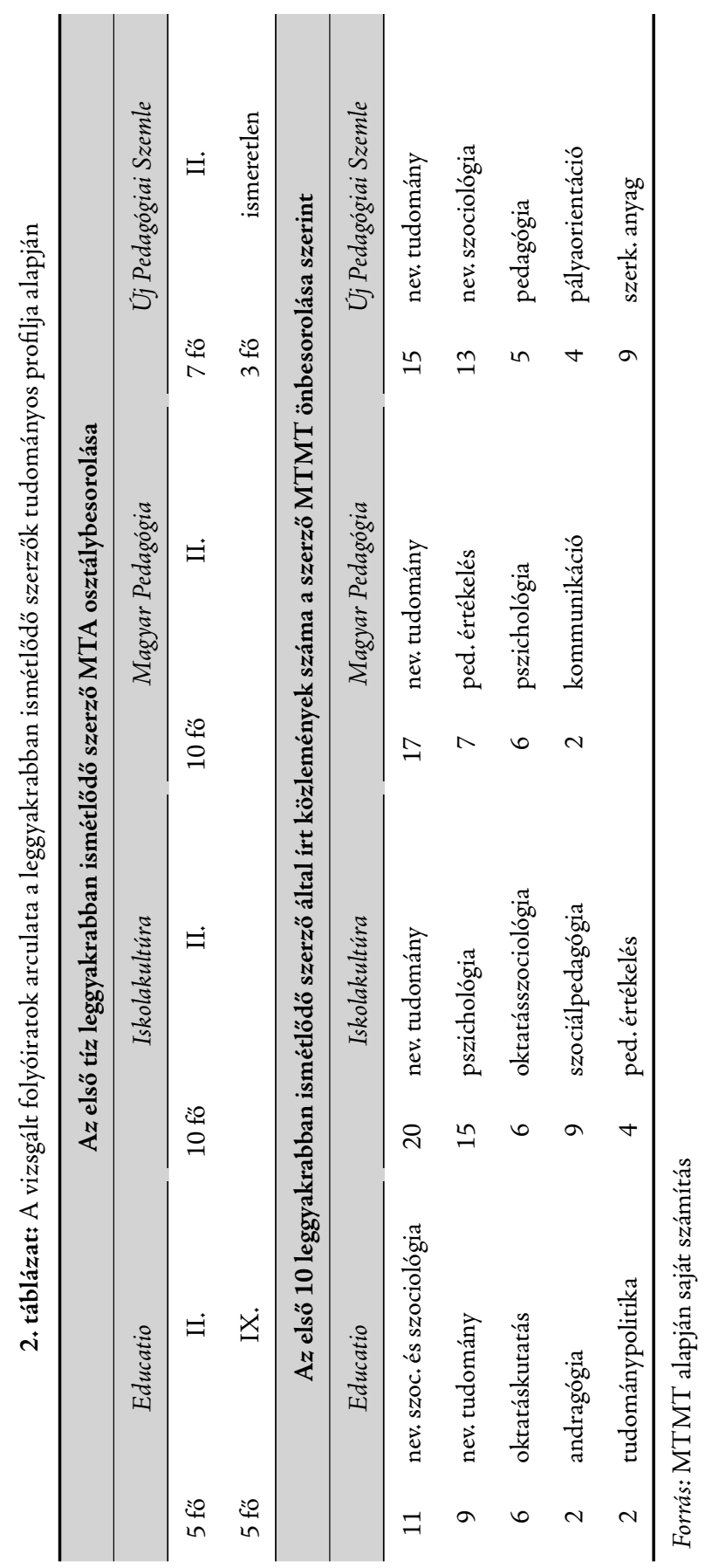


A $z$ adatok tanúsága szerint mind a négy folyóirat meghatározóan a neveléstudományi intézetek vezető oktatói publikációinak ad teret. Ehhez képest mind a szociológiai intézetek, mind a pszichológiai intézetek vezető oktatói meglehetősen szerény közreműködést mutatnak mind a négy periodikában.

Sasvári és szerzőtársa (Sasvári-Urbanovics 2021) elemezte a gazdaságtudományi terület elfogadott folyóiratainak publikációs és hivatkozási tendenciáit 2018-2020 között, és azt találták, hogy az Educatio 2018-ban 65, 2019-ben 48, az Iskolakultúra 2018-ban 62, 2019-ben 72 gazdasági tárgyú közleményt tett közzé. Ha ezt átszámítanánk a fentiek szerinti fajlagos mutatóra, akkor a szociológiai és a pszichológiai terület eredményeinél valamivel alacsonyabb értékeket kapnánk.

Összességében tehát mind a négy folyóirat alapvetően neveléstudományi irányultságú, amihez némelyiknél több, némelyiknél kevesebb kitekintés társul.

$\mathrm{A} z$ adatokból egyértelmü, hogy a négy vizsgált folyóirat a neveléstudományi intézetek vezető oktatóinak közléseiben játszik meghatározó szerepet. A folyóiratok közlési intenzitását is figyelembe vevő elemzés szerint különösen jól látszanak az egyes egyetemek ezen intézeteinek preferenciái is. A debreceniek az Educatiót preferálják, a szegediek az Iskolakultúrát és a Magyar Pedagógiát, a pécsiek az Magyar Pedagógiát, az ELTE oktatói pedig elsősorban a Magyar Pedagógiát. Az is látszik, hogy a szociológiai intézetek vezető oktatói - ezen négy folyóiratban elhelyezett írásait illetően - az Educatiót preferálják, a pszichológiai intézetek vezető oktatói pedig a Magyar Pedagógiát és az Iskolakultúrát, de ezek a közlési gyakoriságok messze elmaradnak a neveléstudományi intézetek oktatóiétól.

\section{$\mathrm{Az}$ Educatio szerzői és szerkesztői}

Az Educatio folyóiratban 1992 és 2020 között kicsit több mint ezer (1019) tanulmány ${ }^{7}$ jelent meg. A szerzők megoszlását vizsgálva egy jellemzően exponenciális eloszlást találunk (1. ábra).

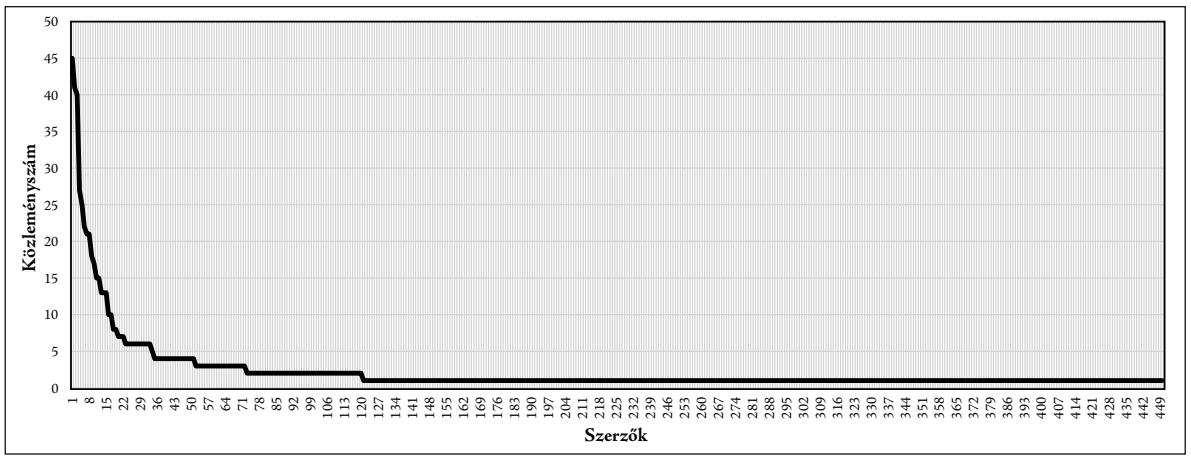

1. ábra: Az Educatio szerzőinek megoszlása a folyóiratban közölt publikációik száma alapján. Forrás: saját kigyüjtés alapján saját szerkesztés

Az Educatio közlési szerkezetében nagyjából négy közleménytípus különíthető el: a tudományos tanulmányok, az interjúk, a recenziók, illetve szemlék, valamint a rövid kutatási beszámolók. Itt a tanulmány vagy hasonló címszó alatt megjelent jelentősebb tudományos írások számbavételéről van szó. 
17 olyan szerző van, aki több mint 10 tanulmányt közölt a folyóiratban, ők adták az összes tanulmány jellegű publikáció 36\%-át. További 17 szerző, aki 5 és 9 közötti tanulmányt adott közre, ami az összes tanulmány 11\%-a. További 86 szerző publikált 2, 3 vagy 4 alkalommal, ez teszi ki a tanulmányok további 22\%-át. A fennmaradó valamivel több mint 300 közlemény további valamivel több mint 350 szerző között oszlik meg, azaz a tanulmányok mintegy 450 szerző tollából származnak.

A fentiekhez hozzá kell tenni, hogy a szerzőismétlődésben az Educatio egyáltalán nem egyedülálló. Ha megvizsgáljuk a négy elemzett folyóirat legutóbbi három évfolyamának írásait (az OPKM WebOPAC adatai alapján), akkor azt találjuk, hogy a szerzőismétlődés - azaz az ismétlődő szerzők számának és az összes szerző számának hányadosa - az Iskolakultúra és a Magyar Pedagógia esetében 20\% körüli, az Educatio és az Új Pedagógiai Szemle esetében pedig 14\% körüli. Ha a négy folyóirat MTMT-ben található összes közleményének leggyakoribb szerzőjét nézzük, akkor az Educatióban a leggyakoribb szerző az összes írás 4,4\%-át, az Iskolakultúrában 3\%-át a Magyar Pedagógiában 5,7\%-át, az Új Pedagógiai Szemlében pedig 4\%-át adja.

Ha az Educatio legtermékenyebb szerzőinek tudományági hovatartozását vizsgáljuk, akkor azt találjuk, hogy a 17 közül: 12 neveléstudományokból, 4 szociológiai tudományokból 1-1 pedig történelemtudományból, illetve közgazdaságtudományból rendelkezik tudományos minősítéssel. ${ }^{8} \mathrm{Ha}$ az MTMT-ben nézzük meg, hogy ki milyen tudományterületre sorolta magát, akkor valamivel változatosabb képet kapunk. Az adatok szerint az egyik meghatározó irányultság a szociológiai (ha idesoroljuk a szociológiai, nevelésszociológiai és az oktatásszociológiai besorolásokat), ami 44\%-ot tesz ki. A másik, ezt részben átfedő irányultság a neveléstudományi (ha ebbe soroljuk a nevelésszociológiai, a neveléstudományi, az oktatáskutatási és oktatáspolitikai besorolást), ez $56 \%$ súlyú.

A szerkesztőbizottság tagjainak tudományági hovatartozását is érdemes megvizsgálni, ugyanis az Educatio folyóirat esetében a szerkesztőbizottság - más folyóiratoktól eltérően, ahol az egy reprezentatív, a lap irányvonalát megtestesítő, lényegében virtuális testület - itt gyakorlati szerkesztőségként, a lapszámok aktív alakítójaként is müködik. A 16 tag $^{9}$ mindegyike tudományos minősítéssel rendelkezik, közülük 10 neveléstudományok, 4 szociológiai tudományok, 2 gazdaságtudományok tudományterületen (mivel egy tagnak két tudományágban van minősítése, van egy történelemtudományi minősítés is). Az MTMT-beli önbesorolás alapján a neveléstudományi irányultság (a neveléstudományi, az oktatáspolitikai és az oktatáskutatási besorolások) valamivel dominánsabb részarányt, 50\%-ot képviselnek, mint a szociológiai (szociológia, nevelésszociológia, oktatásszociológia) irányultság (44\%). Ez lényegében összhangban van az elöl bemutatott arculatelemzés eredményével.

A domináns szerzők és a szerkesztőbizottság tudományos irányultsága alapján leszögezhető, hogy az Educatio folyóiratot a neveléstudományi és a szociológiai, nevelésszociológiai irányultság jellemzi.

\footnotetext{
Egy szerzőnek két tudományból is van minősítése, így az összeg több mint 17.

9 Fehérvári Anikó, Bajomi Iván, Biró Zsuzsanna Hanna, Csákó Mihály, Forray R. Katalin, Györgyi Zoltán, Hrubos Ildikó, Kováts Gergely, Kozma Tamás, Lukács Péter, Nagy Péter Tibor, Polónyi István, Sáska Géza, Széll Krisztián, Tomasz Gábor, Veroszta Zsuzsa.
} 


\section{$\mathrm{A} z$ Educatio folyóirat tudományos hatása}

A folyóirat tudományos hatását több megközelítésben vizsgáljuk. Az egyik - a legáltalánosabban használt hatásmérőszám - az egy közleményre jutó hivatkozások száma. Egy további a neveléstudományi doktori mühelyek oktatóinak tudományos folyóirat-közleményeiben az Educatio-cikkek aránya, a másik a Magyar Tudományos Akadémia Pedagógiai Tudományos Bizottsága tagjainak folyóirat-közleményeiben az Educatio aránya. Végül pedig a neveléstudományi mühelyek és az MTA PTB tagjai közleményeinek hivatkozásaiban képviselt aránya.

\section{Egy közleményre jutó hivatkozások száma}

A legáltalánosabban használt folyóirat hatásmérési módszer az egy publikációra jutó hivatkozások száma. Az egy közleményre jutó citációk száma a Magyar Pedagógia esetében a legmagasabb, ezt követi az Educatio (3. táblázat). Ha azt is megnézzük, hogy az egyes folyóiratok esetében melyik folyóirat közleményére található a legtöbb hivatkozás, akkor azt látjuk, hogy az Iskolakultúra kivételével mindegyik folyóirat esetében a saját közleményekre található a legtöbb citáció. Az Iskolakultúra írásai viszont legtöbbet a Magyar Pedagógiára hivatkoznak.

3. táblázat: Az egy publikációra jutó hivatkozások száma

\begin{tabular}{lccccc}
\hline & $\begin{array}{c}\text { Összes citáció / } \\
\text { Összes közlemény }\end{array}$ & EDU & IK & MP & ÚPSZ \\
\hline Educatio & 2,41 & 0,39 & 0,07 & 0,04 & 0,04 \\
Iskolakultúra & 1,92 & 0,12 & 0,22 & 0,09 & 0,04 \\
Magyar Pedagógia & 3,98 & 0,07 & 0,34 & 0,41 & 0,10 \\
Új Pedagógiai Szemle & 2,29 & 0,17 & 0,12 & 0,06 & 0,20 \\
\hline
\end{tabular}

Forrás: MTMT alapján saját számítás

A táblázat abból a szempontból is érdekes, hogy jellemzi az egyes lapok önálló kultúráját, mivel a saját közleményekre történt hivatkozás úgy is értelmezhető, hogy egyfajta szemléleti, kulturális kompaktság.

\section{A neveléstudományi mübelyek oktatóinak tudományos folyóirat-közleményeiben az Educatio aránya}

Az egyik megközelítés a hazai doktori programmal rendelkező neveléstudományi intézetek vezető (tanár és docens besorolású) oktatóinak az Educatio folyóiratban közreadott tudományos közleményeinek száma és aránya a másik három széles körben ismert hasonló neveléstudományi folyóiratokhoz viszonyítva (4. táblázat). 
4. táblázat: A neveléstudományi doktori programmal rendelkező egyetemi neveléstudományi intézetek vezető oktatói által a négy pedagógiai folyóiratban közreadott tudományos folyóiratcikkek megoszlása az MTMT alapján

\begin{tabular}{|c|c|c|c|c|c|c|}
\hline & 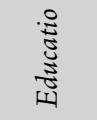 & $\frac{\sqrt{3}}{\frac{9}{9}}$ & 高 & $\hat{\omega}$ & & \\
\hline ELTE Neveléstudományi Intézet & 32 & 73 & 64 & 56 & 225 & $27 \%$ \\
\hline $\begin{array}{l}\text { DE Neveléstudományi Intézet } \\
\text { (Neveléstudományi Tsz.) }\end{array}$ & 140 & 31 & 19 & 23 & 213 & $25 \%$ \\
\hline PTE Neveléstudományi Intézet & 7 & 24 & 6 & 7 & 44 & $5 \%$ \\
\hline SZTE Neveléstudományi Intézet & 9 & 142 & 88 & 41 & 280 & $33 \%$ \\
\hline \multirow[t]{3}{*}{$\begin{array}{l}\text { EKE Neveléstudományi Intézet } \\
\text { (Pedagógia Tsz.) }\end{array}$} & 7 & 26 & 24 & 17 & 74 & $9 \%$ \\
\hline & 195 & 296 & 201 & 144 & 836 & $100 \%$ \\
\hline & $23 \%$ & $35 \%$ & $24 \%$ & $17 \%$ & $100 \%$ & \\
\hline $\begin{array}{l}\text { Az adott folyóiratban megjelent összes } \\
\text { közlemény az MTMT alapján }\end{array}$ & 1297 & 2755 & 812 & 1656 & & \\
\hline $\begin{array}{l}\text { A vizsgált NI intézetek részesedése az } \\
\text { adott folyóirat összes közleményébőll }\end{array}$ & $15 \%$ & $11 \%$ & $25 \%$ & $9 \%$ & & \\
\hline Legtöbbet publikáló intézet & $\begin{array}{c}\mathrm{DE} \\
(11 \%)\end{array}$ & $\begin{array}{l}\text { SZTE } \\
(5 \%)\end{array}$ & $\begin{array}{l}\text { SZTE } \\
(11 \%)\end{array}$ & $\begin{array}{l}\text { ELTE } \\
(3 \%)\end{array}$ & & \\
\hline
\end{tabular}

Forrás: MTMT (2020. májusi állapot) alapján saját számítás

$\mathrm{A} z$ adatok tanúsága szerint a Magyar Pedagógia közleményeinek negyedét, az Educatióénak 15\%-át az Iskolakultúrának és az Új Pedagógiai Szemlének pedig mintegy $10 \%$-át az öt neveléstudományi intézet vezetői oktatóinak közleményei adják. Ugyanakkor mindegyik neveléstudományi műhelynek megvan a maga priorizált (mondhatni „kedvenc") hazai pedagógiai folyóirata. A Debreceni Egyetem neveléstudományi műhelye az, amelyik legnagyobb arányban az Educatio folyóiratban publikál (a folyóirat összes közleményének 11\%-át ők adták). A szegediek a Magyar Pedagógiába és az Iskolakultúrába írnak leggyakrabban (az előbbi írásainak 11\%-át ők adják). Az ELTE neveléstudományi mühelye tagjainak írásai egyenletesebben oszlanak meg a négy lap között, de az ő esetükben is megfigyelhető az Iskolakultúra és a Magyar Pedagógia dominanciája, mint ahogy a PTE esetében is.

$\mathrm{A} z$ egyes folyóiratok valódi súlyának és jelentőségének megítélését reálisabbá teszi, ha a többi hazai és a külföldi folyóiratokban elhelyezett cikkeket is figyelembe vesszük (5. táblázat). 
5. táblázat: A neveléstudományi doktori programmal rendelkező egyetemi neveléstudomány intézetek vezető oktatói által a négy pedagógiai folyóiratban közreadott tudományos folyóiratcikkek és az általuk közreadott összes többi hazai és külföldi folyóiratcikk az MTMT alapján

\begin{tabular}{|c|c|c|c|c|c|c|c|c|}
\hline & 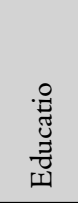 & 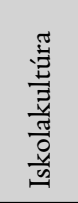 & 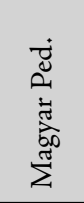 & $\begin{array}{l}N \\
\text { है } \\
\text { Sิ }\end{array}$ & 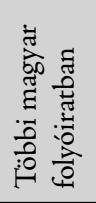 & 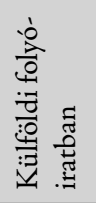 & 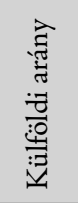 & 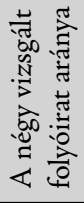 \\
\hline $\begin{array}{l}\text { ELTE Neveléstudományi } \\
\text { Intézet }\end{array}$ & 32 & 73 & 64 & 56 & 236 & 119 & $26 \%$ & $39 \%$ \\
\hline $\begin{array}{l}\text { DE Neveléstudományi Intézet } \\
\text { (Neveléstudományi Tsz.) }\end{array}$ & 140 & 31 & 19 & 23 & 214 & 91 & $21 \%$ & $41 \%$ \\
\hline $\begin{array}{l}\text { PTE Neveléstudományi } \\
\text { Intézet }\end{array}$ & 7 & 24 & 6 & 7 & 80 & 8 & $6 \%$ & $33 \%$ \\
\hline $\begin{array}{l}\text { SZTE Neveléstudományi } \\
\text { Intézet }\end{array}$ & 9 & 142 & 88 & 41 & 83 & 78 & $21 \%$ & $63 \%$ \\
\hline \multirow[t]{2}{*}{$\begin{array}{l}\text { EKE Neveléstudományi } \\
\text { Intézet (Pedagógia Tsz.) }\end{array}$} & 7 & 26 & 24 & 17 & 101 & 33 & $19 \%$ & $36 \%$ \\
\hline & 195 & 296 & 201 & 144 & 714 & 329 & $21 \%$ & $44 \%$ \\
\hline Magyar folyóiratok között & $13 \%$ & $19 \%$ & $13 \%$ & $9 \%$ & $46 \%$ & & & \\
\hline Összes folyóirat között & $10 \%$ & $16 \%$ & $11 \%$ & $8 \%$ & $38 \%$ & $18 \%$ & & \\
\hline
\end{tabular}

Forrás: MTMT (2020. májusi állapot) adatai alapján saját számítás

Szembetűnő, hogy az általunk vizsgált négy hazai neveléstudományi folyóirat aránya 44\%-nyi, legkisebb a súlya a PTE, legnagyobb az SZTE vezető neveléstudományi oktatói közleményeiben. Az is jól látható, hogy a külföldi publikációk aránya valamivel több mint $20 \%$. Továbbra is szembetűnő a négy folyóirat publikációiban bizonyos polarizáltság. A debreceniek alig publikálnak a Magyar Pedagógiában, a szegediek alig publikálnak az Educatióban, ami a két mühely eltérő tudományos orientációja miatt részben érthető is. De a két mühely között ezen túlmutató feszültségek is érzékelhetők, amelyek elemzése túlmutat ennek az írásnak a keretein.

$\mathrm{A} z$ is látszik, hogy az Educatio az öt neveléstudományi műhely vezető oktatóinak publikációi között mintegy 13\%-ot képvisel az összes hazai publikációjukat tekintve, ami nagyjából azonos a Magyar Pedagógiáéval, s mintegy 6 százalékponttal elmarad az Iskolakultúra mögött. Az összes folyóirat-publikációt tekintve (beleértve a külföldi folyóiratokat is) ugyanez az arány $10 \%$.

A külföldi publikációk aránya az ELTE Neveléstudományi Intézetének vezető oktatói esetében a legmagasabb, de a debreceniek és a szegediek esetében is több mint $20 \%$. Időben vizsgálva egyértelműen látszik a hazai folyóiratok lassú háttérbe szorulása a külföldi publikációk mögött.

Végül is a négy vizsgált pedagógiai folyóirat a hazai vezető neveléstudományi szakemberek publikációinak alig felét közli. 


\section{A Magyar Tudományos Akadémia Pedagógiai Tudományos Bizottsága tagjainak folyóirat-közleményeiben az Educatio aránya}

Az Educatio súlyának megítélésére egy másik lehetőség, ha megvizsgáljuk az akadémia pedagógiai bizottsága tagjai publikációiban a folyóirat részesedését. Ha elemezzük az MTA Pedagógiai Bizottsága tagjainak folyóirat-publikációit az MTMT alapján, akkor nagyjából hasonló képet kapunk, mint a neveléstudományi mühelyek elemzése alapján (6. táblázat).

A bizottság tagjai hazai publikációinak fele jelenik meg a négy vizsgált pedagógiai folyóiratban (9\%-a az Educatióban, 16\% az Iskolakultúrában, 12-12\% a Magyar Pedagógiában és az Uj Pedagógiai Szemlében). Az is látszik, hogy a bizottság tagjai adták a Magyar Pedagógia folyóirat összes közleményének ötödét (ami bizonyos szempontból érthető, hiszen a folyóirat a Bizottság lapja).

6. táblázat: MTA Pedagógiai Tudományos Bizottság tagjai folyóiratcikk-közleményeinek megoszlása az MTMT alapján

\begin{tabular}{|c|c|c|c|c|c|}
\hline & Darab & $(\%)$ & $(\%)$ & $\begin{array}{l}\text { A négy folyóirat összes köz- } \\
\text { leménye az MTMT-ben }\end{array}$ & $\begin{array}{l}\text { Bizottsági } \\
\text { arány (\%) }\end{array}$ \\
\hline $\begin{array}{l}\text { Összes (hazai és külföldi) } \\
\text { folyóiratcikk }\end{array}$ & 1769 & & 100 & & \\
\hline Összes hazai folyóiratcikk & 1462 & 100 & 83 & & \\
\hline \multicolumn{6}{|l|}{ Hazai folyóiratcikkből } \\
\hline az Educatio & 132 & 9 & 7 & 1297 & 10 \\
\hline az Iskolakultúra & 240 & 16 & 14 & 2755 & 9 \\
\hline a Magyar Pedagógia & 174 & 12 & 10 & 812 & 21 \\
\hline az Új Pedagógiai Szemle & 179 & 12 & 10 & 1656 & 11 \\
\hline Többi magyar folyóiratcikk & 737 & 50 & 42 & & \\
\hline Külföldi folyóiratcikk & 307 & & 17 & & \\
\hline
\end{tabular}

Forrás: MTMT (2020. májusi állapot) adatai alapján saját számítás

Ha figyelembe vesszük a folyóiratok közlési intenzitását (azaz a közreadott és az MTMT-ben rögzített publikációk számát), akkor egyértelmüen a Magyar Pedagógia áll az élen $21 \%$-kal, a másik három periodika nagyjából hasonló, 10\%-os súlyával szemben.

Ha megvizsgáljuk a bizottsági tagok életkora és a különböző folyóiratokban közreadott publikációk számának kapcsolatát, akkor azt találjuk, hogy az Educatio esetében a legmagasabb a korreláció $(+0,3353)$, amit a Magyar Pedagógia követ $(+0,3352)$ - ugyanakkor az Iskolakultúra esetében gyakorlatilag nincs kapcsolat $(+0,0506)$ és az ÚPSZ esetében is elhanyagolható $(+0,1659)$. Ebből arra lehet következtetni, hogy az Educatióban az idősebbek publikálnak nagyobb valószínűséggel, ami nem igazán meg- 
lepő, mivel az Educatio tanulmányrovatában alapvetően meghívásos alapon kerülnek be a szerzők, s a szerkesztőbizottság alighanem törvényszerűen ismert - s ebből adódóan idősebb - szerzőket invitál meg.

\section{Melyik folyóiratban publikál több „elit”}

Gyakran felmerül egyik vagy másik folyóirat esetében, hogy színvonalukat azzal igyekeznek bizonyítani, hogy szerzőik között magas az „elit” szerzők aránya. Ezt persze nehéz igazolni, mert az „elit” azonosítása definíció kérdése.

Itt mi most megkíséreljük többé-kevésbé objektív módon mérni az elit szerző fogalmát. Azokat a szerzőket tekintjük elitnek, akik a Scientometrics of Hungarian researchers adatbázis adatai alapján D1 és D2 besorolásúak.

Mind a négy folyóirat esetében az utolsó megjelent három évfolyam írásainak a közlési gyakoriság szerint sorba rendezett szerzők alapján az első negyven publikáció írója között a Scientometrics of Hungarian researchers adatai alapján D1 és D2 besorolásúak számát mutatja a 7. táblázat (2020. év végi állapot).

7. táblázat: Az „elit” (D1 és D2 besorolású) szerzők száma

\begin{tabular}{|c|c|c|c|c|c|c|c|}
\hline \multicolumn{2}{|c|}{ Educatio } & \multicolumn{2}{|c|}{ Iskolakultúra } & \multicolumn{2}{|c|}{ Magyar Pedagógia } & \multicolumn{2}{|c|}{ Új Pedagógiai Szemle } \\
\hline \multicolumn{8}{|c|}{$\begin{array}{l}\text { A közlési gyakoriság szerint sorba rendezett szerzők alapján az első negyven publikáció írói } \\
\text { között a Scientometrics of Hungarian researchers adatai alapián D1 és D2 besorolású }\end{array}$} \\
\hline 4 fó & D1 & 3 fö & D1 & 4 fö & D1 & 1 fö & D1 \\
\hline 3 fö & D2 & 2 fó & D2 & 1 fö & D2 & 1 fö & D2 \\
\hline \multicolumn{8}{|c|}{ A vizsgált három évfolyam összes közleménye } \\
\hline 145 & & 236 & & 49 & & 226 & \\
\hline \multicolumn{8}{|c|}{ D1+D2 besorolásúak a közleményekhez viszonyítva } \\
\hline $5 \%$ & & $2 \%$ & & $10 \%$ & & $1 \%$ & \\
\hline
\end{tabular}

Forrás: OPKM WebOPAC (https://opac.opkm.hu/pages/modules/opac/opac.php?fn=as), valamint Scientometrics of Hungarian researchers (https://www.tudomanymetria.com/) alapján saját számítás

$\mathrm{A} z$ adatok tanúsága szerint a közleményszámhoz viszonyított elit szerző aránya a Magyar Pedagógiában a legmagasabb, az Educatio a második. Az Iskolakultúra és az Új Pedagógiai Szemle szerényebb adatokról tanúskodik ebből a szempontból, ami alapvetően érthető, hiszen ezeknek a folyóiratoknak a szerzői között van a legtöbb PhD-hallgató, illetve gyakorló szakember.

\section{$\mathrm{Az}$ Educatio hatása a vezető oktatók hivatkozásaiban}

$\mathrm{Az}$ Educatio folyóirat hatását egy másik módszerrel úgy próbáltuk megítélni, hogy az öt neveléstudományi műhely egyetemi tanárainak (emeritusok nélkül ez 13 főt jelent) 
megnéztük az MTMT-ben megadott legutóbbi 5 magyar nyelvű folyóirat-publikációját. E folyóiratok hivatkozásaiban megszámoltuk az általunk vizsgált négy pedagógiai folyóiratban megjelent írásokra való citációk számát. Miután az egyetemi tanárok száma intézetenként jelentősen eltér, ezért az intézményi átlagos hivatkozások folyóiratonként számított összegének megoszlását vizsgáltuk (2. ábra).

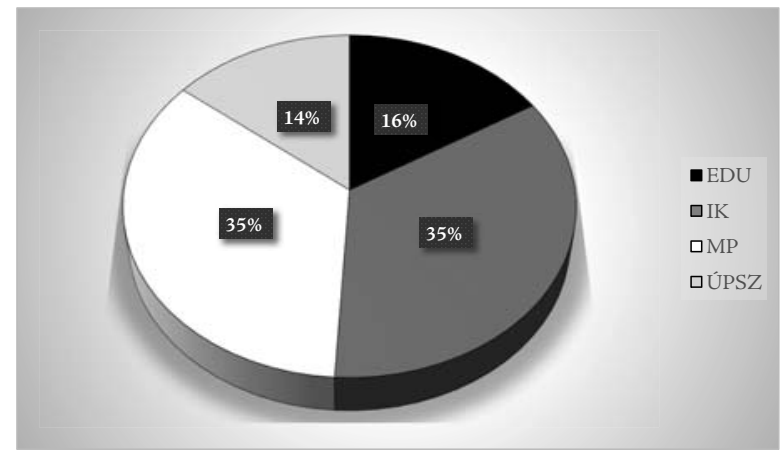

2. ábra: Az NI egyetemi tanárok hivatkozásainak megoszlása a négy pedagógiai folyóirat között. Forrás: MTMT (2020. májusi állapot) adatai alapján saját számítás

A közleményszámmal korrigált hivatkozásmegoszlás a Magyar Pedagógia arányát jelentősen megnöveli, az Iskolakultúráét pedig lecsökkenti, de az Ediucatio helyén nem változtat (3. ábra).

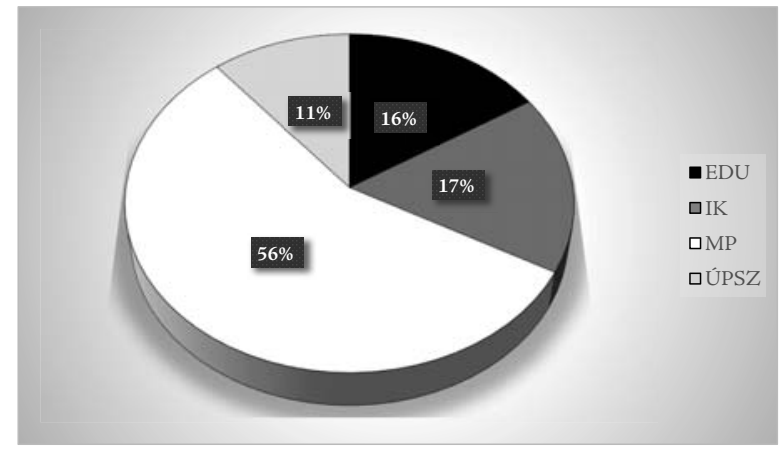

3. ábra: Az NI egyetemi tanárok hivatkozásainak megoszlása a négy pedagógiai folyóirat között - közleményszámmal korrigált adatok. Forrás: MTMT (2020. májusi állapot) adatai alapján saját számítás

A neveléstudományi intézetek egyetemi tanárainak a négy folyóirat közötti hivatkozás eloszlásában (4. ábra) a Magyar Pedagógia és az Iskolakultúra azonos részesedéssel vezet, az Educatio ezek részesedési arányának kevesebb mint felével a harmadik, kicsivel megelőzve az Új Pedagógiai Szemlét. Ha megnézzük a fajlagos hivatkozások folyóiratonkénti megoszlását intézetenként némileg hasonló képet kapunk, mint az intézetek vezető oktatóinak publikációmegoszlásában - de lényegesen kiélezettebben. A debreceniek nem hivatkoznak a Magyar Pedagógiára, a szegediek nem hivatkoznak az Educatióra. 


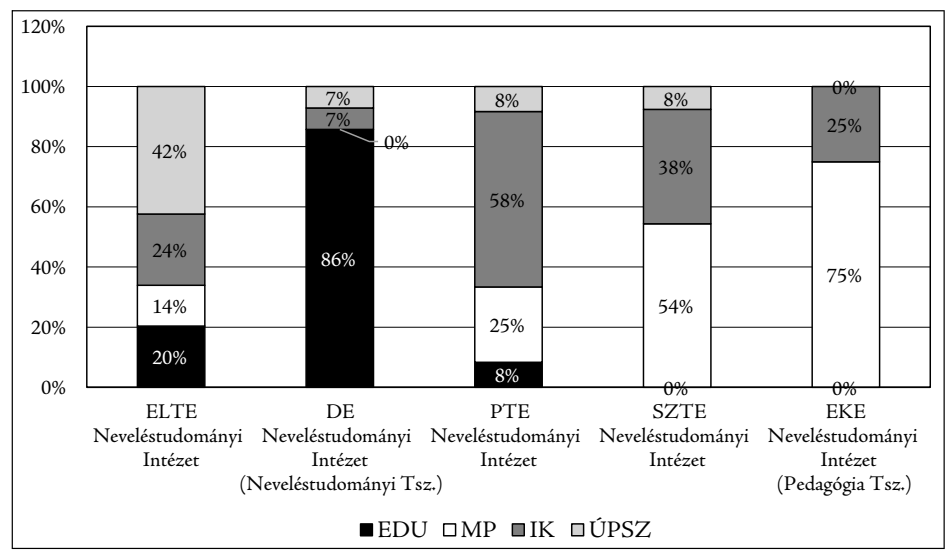

4. ábra: Az NI egyetemi tanárok hivatkozásainak megoszlása a négy pedagógiai folyóirat között intézetenként. Forrás: MTMT (2020. májusi állapot) adatai alapján saját számítás

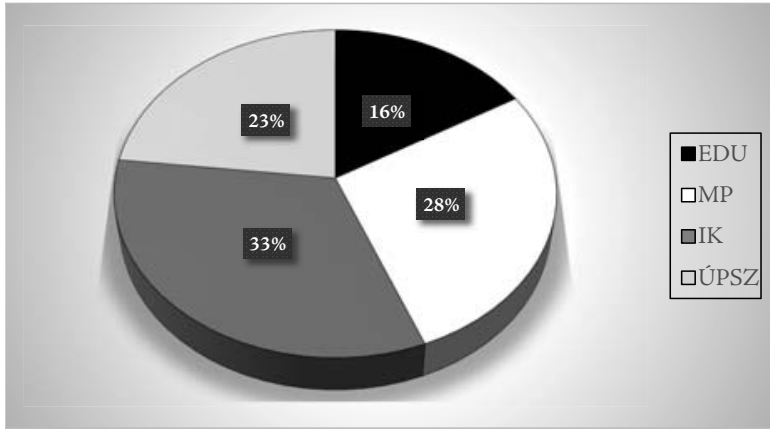

5. ábra: Az MTA Pedagógiai Tudományos Bizottsága tagjai hivatkozásainak megoszlása a négy pedagógiai folyóirat között. Forrás: MTMT (2020. augusztusi állapot) adatai alapján saját számítás

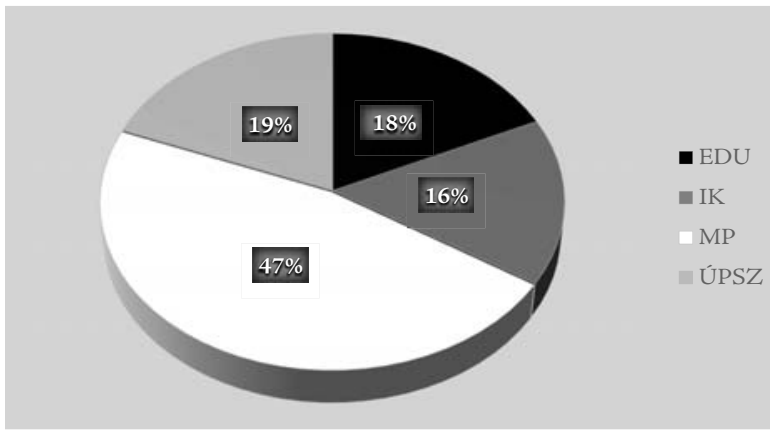

6. ábra: Az MTA Pedagógiai Tudományos Bizottsága tagjai hivatkozásainak megoszlása a négy pedagógiai folyóirat között - közleményszámmal korrigálva. Forrás: MTMT (2020. decemberi állapot) adatai alapján saját számítás 
Az MTA Pedagógiai Tudományos Bizottsága tagjainak a hivatkozásait elemezve (ez esetben is az utolsó öt magyar nyelvü folyóiratcikkbeli hivatkozásokat vizsgálva függetlenül a megjelenés időpontjától) viszonylag jelentős eltérést tapasztalunk (5.ábra) a neveléstudományi műhelyek vezető oktatóihoz viszonyítva. Itt is az Iskolakultúra vezeti a rangsort, a Magyar Pedagógia a második, és a négy folyóiratbeli közleményekre történt összes citáció közül a legkevesebb az Educatio folyóiratban megjelent írásokra vonatkozik.

A közleményszámmal korrigált adatok a Magyar Pedagógia jelentős előnyét mutatják, s a másik három folyóirat nagyjából hasonló részesedését (6. ábra).

\section{Befejezésül}

Elemzésünk arra vállalkozott, hogy megalapításának 30 éves évfordulóján elemezze az Educatio folyóirat néhány tudománymetriai jellemzőjét a magyar folyóiratpiac másik három neveléstudományi folyóiratával összehasonlítva. Mintegy tükröt tartva az Educatio elé.

Ezt mutatja a tükör.

Az értékelést az olvasóra bízzuk.

Köszönettel tartozom Sáska Gézának értékes észrevételeiért.

\section{IRODALOM}

Bıró Zs. H. (2009a) A magyar neveléstudományi kommunikáció szereplői. Tudományszociológiai elemzés a központi pedagógiai folyóiratok szerzőiről (1997-2006). In: NÉMETH A. \& Biró Zs. H. (eds) A magyar neveléstudomány a 20. század második felében. Budapest, Gondolat. pp 168-209.

Bıró Zs. H. (2009b) A magyar neveléstudományi kommunikáció jellemzői (1997-2006). Összehasonlító tudományszociológiai elemzés, avagy kísérlet egy nemzetközi kutatás adaptációjára. Magyar Pedagógia, Vol. 109. No. 1. pp. 49-76.

Csapó B. (1991) Hagyomány és korszakváltás. A megújult Magyar Pedagógia programja. Magyar Pedagógia, Vol. 91. No. 1. pp. 3-6.

Csapó B. (1992) Száz év - Száz éves a Magyar Pedagógia. Magyar Pedagógia, Vol. 92. No. 1. pp. 3-4.

Csapó B. (2005) A Magyar Pedagógia feladata a neveléstudomány fejlesztésében. Iskolakultúra, Vol. 15. No. 4. pp. 3-10.

GÉczi J. (2001) A magyar pedagógiai szaksajtóról. In: Csapó B. \& VidÁkovich T. (eds) Neveléstudomány az ezredfordulón. Budapest, Nemzeti Tankönyvkiadó. pp. 392-402.

Molnár P., Pintér H. \& Tóth E. (2018) A neveléstudomány társszerzői együttmüködéseinek hálózatai hazai és nemzetközi folyóiratokban. Jel-kép, No. 4. DOI: 10.20520/ JEL-KEP.2018.4.19

Nagy Gy. (2016) Tudománymetria és neveléstudomány. Iskolakultúra, Vol. 26. No. 2. pp. 50-62.

NAGy Gy. (2019) A Magyar Pedagógia folyóirat tudománymetriai és tartalomelemzése. PhD-értekezés. SZTE Neveléstudományi Doktori Iskola. 
Nagy G. \& MolnáR G. (2017) A Magyar Pedagógia folyóirat tudománymetriai elemzése: tendenciák, szerzők, társszerzőségi együttműködés. Magyar Pedagógia, Vol. 117. No. 1. pp. 5-27.

SAsvári P. (2019) Az MTA IX. Osztály hazai folyóiratainak H-indexe és az összes dokumentumainak a száma az MTMT alapján. DOI: 10.13140/RG.2.2.27122.56001

Sasvári P. \& Urbanovics A. (2020) Mérlegen az MTA IX. osztály hazai listás folyóiratai - hazai és nemzetközi hivatkozások összevetése. Tudomány és Müszaki Tájékoztatás, Vol. 67. Nos 7-8. pp. 411-448. https://tmt.omikk.bme.hu/tmt/article/view/12675 [Letöltve: 2021. 03. 17.]

Sasvári P. \& Urbanovics A. (2021) Az MTA IX. Gazdaság-és Jogtudományok Osztály hazai folyóiratainak hivatkozás-és h-index-alapú helyezése. DOI: 10.13140/ RG.2.2.14074.82884

Soós S., Kiss A. \& Lackner Z. (2020) A tudománymetria elmélete a gyakorlatban: a tudományklasszifikáció problematikája. Statisztikai Szemle, Vol. 98. No. 8. pp. 958-980. DOI: https://doi.org/10.20311/stat2020.8.hu0958

Soós S. \& Vida Zs. (2019) Kutatásértékelés és tudománymetria. Mérőszámok, tendenciák, hazai vonatkozások. Előadás a „Tudománymetria, barát vagy ellenség” konferencián 2019. november 29.

Tóth I. J., Toman N. \& Cserpes T. (2008) A magyar neveléstudomány tudományos aktivitásának felmérése empirikus eszközökkel. - Kutatási zárótanulmány. Budapest, Wargo Közgazdasági Elemző- és Piackutató Intézet.

\section{MELLÉKLET}

1. táblázat: A neveléstudományi intézetek vezető oktatóinak egy főre vetített folyóiratpublikációi a négy vizsgált folyóiratban

\begin{tabular}{|c|c|c|c|c|c|c|c|c|}
\hline & EDU & IK & MP & ÚPSZ & $E D U$ & $I K$ & $M P$ & ÚPSZ \\
\hline $\mathrm{DE}$ & 15,56 & 3,44 & 2,11 & 2,56 & 15,56 & 2,12 & 6,25 & 1,64 \\
\hline ELTE & 2,13 & 4,87 & 4,27 & 3,73 & 2,13 & 2,99 & 12,63 & 2,40 \\
\hline PTE & 3,50 & 12,00 & 3,00 & 3,50 & 3,50 & 7,37 & 8,88 & 2,25 \\
\hline SZTE & 1,00 & 15,78 & 9,78 & 4,56 & 1,00 & 9,69 & 28,93 & 2,92 \\
\hline Súlyozott átlag & 5,37 & 7,71 & 5,06 & 3,63 & 5,37 & 4,74 & 14,97 & 2,33 \\
\hline
\end{tabular}

Megjegyzés: A jobb oldali oszlopok az adott folyóirat publikációs intenzitását is figyelembe veszik (a vizsgált három év alatt EDU 145, IK 236, MP 49, ÚPSZ 226 írást adott közre - a jobb oldali négy oszlop az egy vezető oktatóra jutó publikációk számát úgy mutatja, mintha mindegyik az Educatio kiadási intenzitásával müködött volna a vizsgált három évben). 
2. táblázat: A szociológiai intézetek vezető oktatóinak egy főre vetített folyóirat-publikációi a négy vizsgált folyóiratban

\begin{tabular}{|c|c|c|c|c|c|c|c|c|}
\hline & EDU & IK & MP & ÚPSZ & EDU & $I K$ & $M P$ & ÚPSZ \\
\hline $\mathrm{DE}$ & 1,63 & 0,25 & 0,25 & 0,54 & 1,63 & 0,15 & 0,74 & 0,00 \\
\hline ELTE & 0,60 & 0,27 & 0,00 & 0,20 & 0,60 & 0,16 & 0,00 & 0,13 \\
\hline PTE & 0,20 & 0,00 & 0,00 & 0,00 & 0,20 & 0,00 & 0,00 & 0,00 \\
\hline SZTE & 0,50 & 0,00 & 0,00 & 0,00 & 0,50 & 0,00 & 0,00 & 0,00 \\
\hline Súlyozott átlag & 0,80 & 0,20 & 0,07 & 0,23 & 0,80 & 0,12 & 0,20 & 0,06 \\
\hline
\end{tabular}

Megjegyzés: A jobb oldali négy oszlop az adott folyóirat publikációs intenzitását is figyelembe veszi.

3. táblázat: A pszichológiai intézetek vezető oktatóinak egy főre vetített folyóirat-publikációi a négy vizsgált folyóiratban

\begin{tabular}{|c|c|c|c|c|c|c|c|c|}
\hline & EDU & IK & MP & ÚPSZ & $E D U$ & $I K$ & $M P$ & ÚPSZ \\
\hline $\mathrm{DE}$ & 0,00 & 0,62 & 0,85 & 0,54 & 0,00 & 0,38 & 2,50 & 0,35 \\
\hline ELTE & 0,31 & 0,26 & 0,00 & 0,20 & 0,31 & 0,16 & 0,00 & 0,13 \\
\hline PTE & 0,00 & 0,38 & 0,00 & 0,00 & 0,00 & 0,23 & 0,00 & 0,00 \\
\hline SZTE & 0,00 & 3,20 & 1,20 & 0,00 & 0,00 & 1,97 & 3,55 & 0,00 \\
\hline Súlyozott átlag & 0,18 & 0,59 & 0,28 & 0,23 & 0,18 & 0,36 & 0,82 & 0,15 \\
\hline
\end{tabular}

Megjegyzés: A jobb oldali négy oszlop az adott folyóirat publikációs intenzitását is figyelembe veszi.

A cikk a Creative Commons Attribution 4.0 International License (https://creativecommons.org/licenses/ by/4.0/) feltételei szerint publikált Open Access közlemény, melynek szellemében a cikk bármilyen médiumban szabadon felhasználható, megosztható és újraközölhető, feltéve, hogy az eredeti szerző és a közlés helye, illetve a CC License linkje és az esetlegesen végrehajtott módosítások feltüntetésre kerülnek. (SID_1) 